Original article

\title{
Hematological and serum biochemistry parameters as a prognostic indicator of severally ill versus mild Covid-19 patients: A study from tertiary hospital in North India
}

\author{
Deval B. Dubey ${ }^{c}$, Sridhar Mishra ${ }^{\mathrm{b}}$, Himanshu D. Reddy ${ }^{\mathrm{c}}$, Aliya Rizvi ${ }^{\mathrm{a}}$, Wahid Ali ${ }^{\mathrm{a},}$ \\ a Department of Pathology, India \\ ${ }^{\mathrm{b}}$ Department of Pathology, Dr. Ram Manohar Lohia Institute of Medical Sciences, Lucknow, Uttar Pradesh, 226010, India \\ ${ }^{\mathrm{c}}$ Department of Medicine, King George Medical University, India
}

\section{A R T I C L E I N F O}

\section{Keywords:}

COVID-19

Total leucocyte count

C-reactive protein

Lactate dehydrogenase

\begin{abstract}
A B S T R A C T
Background/objectives: In, India coronavirus disease (COVID-19) cases are on the rise in terms of the total number of cases. Findings on clinical and hematological parameters alone carry no significance apart from telling patients present status and hence are diminutive. This study aims to assess the hematological and serum biochemistry parameters and correlate them with the presenting symptoms and severity of disease which can help predict the need for intensive care unit (ICU) care, help in triage, assess the severity of the disease which will help clinicians decide their future course of action and further improve patients clinical outcome.

Methods: A total of 200 COVID-19 positive patients were included. Hematological and serum biochemistry parameters were recorded for the patients at the time of admission and categorized as mild, moderate, and severely ill based on clinical status and then admitted into various wards.

Results: Total leucocyte count (TLC) was significantly different and higher in severely ill patients $(13,200 \pm$ 6,999.2) compared to cases presented with mild and moderate symptoms $(12,100 \pm 6,488.41 \& 8,788.20 \pm$ 4,954.32, $\mathrm{p}=0.001$ ). The mean difference of TLC, Neutrophil\% (N\%), Lymphocyte\% (L\%) and Monocyte (M\%) was significantly different between mild and moderate symptoms cases $(\mathrm{p}=0.030, \mathrm{p}=0.002, \mathrm{p}=0.004 \& \mathrm{p}=$ $0.003)$. Between groups comparison of moderate vs. severely ill cases showed a significant difference in TLC ( $\mathrm{p}=$ 0.000), $\mathrm{N} \%(\mathrm{p}=0.000), \mathrm{L} \%(0.000)$, and $\mathrm{L} / \mathrm{N}$ ratio $(\mathrm{p}=0.002)$. The serum ionic calcium $(\mathrm{Ca})$, random blood sugar (RBS), C-reactive protein (CRP), fibrinogen, prothrombin (PT), International Normalized Ratio (INR), ferritin, and Lactate Dehydrogenase (LDH) level also differed significantly between mild, moderate and severely ill cases $(\mathrm{p}=0.001, \mathrm{p}=<0.001, \mathrm{p}=0.002, \mathrm{p}=<00.1, \mathrm{p}=0006, \mathrm{p}=0.005, \mathrm{p}=<0.001$ and $\mathrm{p}=<0.001$ ) respectively. Comparison of the mild vs. severely ill cases showed a significant difference in urea, fibrinogen, and procalcitonin (PCT) level ( $\mathrm{p}=0.005, \mathrm{p}=0.000 \& \mathrm{p}=0.048$ ) respectively.

Conclusion: The preliminary findings of this study suggest hematological and serum biochemistry parameters could be used as a screening tool to identify patients requiring intensive care and thus allowing clinical stratification and triage at the time of presentation.
\end{abstract}

\section{Introduction}

The coronavirus disease (Covid-19) was declared as a pandemic in January 2020 by World Health Organization (WHO). It has affected more than 216 countries. Currently, more than 43 million cases were diagnosed with 1.1 million death resulted from the disease. The case and death in India are also higher affecting 7.9 million with more than 0.1 million death. ${ }^{1}$ Early symptoms of the virus infection show common cold symptoms such as fever and swelling of the throat and can develop various conditions, including respiratory, enteric, neurological, and hepatic diseases including Acute Respiratory Distress Syndrome (ARDS), acute cardiac injury, or secondary infection. ${ }^{2,3}$ In patients group with underlying medical conditions and elderly patients, the severe respiratory disease may develop causing death. ${ }^{4}$ The present COVID-19 situation disrupted the health and health services in India in various ways. Studies have found increase in diabetes related problem due to the

\footnotetext{
* Corresponding author. Department of Pathology, King George Medical University, Lucknow, UP, 226003, India.

E-mail address: aliwahid78@gmail.com (W. Ali).
} 
COVID-19 lockdown, resulting in higher rate of cardiovascular complication that have potential to increase the severity in COVID-19 patients. In ongoing pandemic optimization of limited technical resources is of importance. The use of routine blood investigation parameters as a marker of disease severity will results in improved clinical awareness to identify the target patients at higher risk. Early diagnosis is vital when considering the short time of onset of acute respiratory distress syndrome after admission to hospital and the high mortality rates in the COVID-19 patients. ${ }^{5}$ A simple blood test may have an important role in the diagnosis \& monitoring of disease condition, as the test provides the information of the inflammatory process including leucocyte count and other characteristics such as neutrophil- or lymphocyte-dominance, neutrophil-lymphocyte ratio (N/L ratio) C-reactive protein (CRP) as inflammation marker, collateral organ damage (acute renal failure, acute liver failure) and the disease severity. An analysis of blood test results may provide information in terms of the nature of pneumonia, where the physician can determine the etiology of the disease. ${ }^{6}$ As a marker of an inflammatory process, complete blood count (CBC) including platelet count (PLT), neutrophils, lymphocyte, and monocyte count. Neutrophils are an important component of the immune system. Considering the prognostic indicator of COVID-19-positive patients, the use of circulating biomarkers representing inflammation and the immune system may be of great importance. However, the clinical utility in terms of disease diagnosis, monitoring, and risk stratification has not been explored much in detail and depth.,

In this study, we have evaluated the hematological and serum biochemistry parameters in a peripheral blood sample of North Indian COVID-19 patients who have gone to the admission to Intensive care units (ICU) \{Severe\}, High Dependency Units (HDU) \{Moderate\}, or General Ward (Mild) of King George Medical University (KGMU), Lucknow, Uttar Pradesh. These parameters may be used to predict and assess the progression of the disease and precautions can be taken for the patient before the patient's clinical condition become severe and this could help to decrease the number of morbidity and mortality.

\section{Materials and methods}

The current study is a tertiary care hospital and lab-based retrospective pilot study which was carried out in the Department of Pathology, KGMU, Lucknow. Data of patients for blood count parameters and serum biochemistry parameters of patients admitted to COVID ward, ICU/HDU with confirmed positive COVID-19 status by SARSCov2 Qualitative Real Time -Polymerase Chain Reaction (RT-PCR) was collected by a treating clinician as per the standard guideline, between May 2020-July 2020 from Chemical Pathology Laboratory, Department of Pathology, KGMU, Lucknow. The study was approved by the institutional ethics committee of the University. Detailed blood count parameters \& serum biochemistry parameters and demographic profile of the patient were recorded from Laboratory Information system (LIS) of our hospital. . Patients of all age groups \& sex were included who were primarily diagnosed and confirmed by RT-PCR admitted to KGMU, Lucknow. Written and oral informed consent from subjects was waived by the Ethics Committees.

\section{Data collection}

The basic demographic details were collected from the admission records. Other underlying comorbidity and syndromes were not considered at the time of admission. No syndrome considered at the time of admission as healthcare workers/attendant/patients do not always know associated medical condition beforehand. So the clinical, hematological and biochemical examination remains the only way to triage the patients at the time of admission. Whole blood EDTA samples, sent at the time of admission were run on 3 part cell counter for CBC. First reading of prothrombin time (PT) and D-dimer values were obtained from citrated samples carried out on Stago (Satellite analyzer) sent within the first five days of admission. Values for serum CRP, lactate dehydrogenase (LDH) were obtained. Serum biochemistry parameters were done on a biochemistry auto analyzer as per the kit insert using the samples collected in a plain vial. All the test parameters were performed in National Accreditation Board for Testing and Calibration Laboratories (NABL) certified chemical pathology laboratory, department of pathology, KGMU. Calibration performed with standard controls were performed. To avoid the effect of interpolation if any, only the first sent investigation was included. The patient's data were analyzed based on their admission to ICU(Severe), HDU (Moderate), or General Ward (Mild) as per the guideline of the Ministry of Home Affairs, Government of India, New Delhi. ${ }^{7}$ Cases were categorized as Mild: Patients with uncomplicated upper respiratory tract infection may have mild symptoms such as fever, cough (cough, with or without sputum production OR both), sore throat, nasal congestion, malaise, headache without evidence of breathlessness, or Hypoxia (normal saturation). Admitted in general wards, Moderate: Pneumonia with no signs of severe disease Adolescent or adult with the presence of clinical features of dyspnea and or hypoxia, fever, cough, including SpO2 < 94\% (range 90-94\%) on room air, respiratory rate more or equal to 24 per minute. . Admitted in High dependency units, Severe: Severe Pneumonia Adolescent or adult: with clinical signs of Pneumonia plus one of the following; respiratory rate $>30$ breaths/min, severe respiratory distress, $\mathrm{SpO} 2<90 \%$ on room air or ARDS or Sepsis/Septic shock. Sepsis Adults: Acute life-threatening organ dysfunction caused by a dysregulated host response to suspected or proven infection. Signs of organ dysfunction include altered mental status, difficult or fast breathing, low oxygen saturation, reduced urine output, fast heart rate, weak pulse, cold extremities or low blood pressure, skin mottling, or laboratory evidence of coagulopathy, thrombocytopenia, acidosis, high lactate or hyperbilirubinemia. Children: suspected or proven infection and $\geq 2$ age-based Systemic Inflammatory Response Syndrome (SIRS) criteria, of which one must be abnormal temperature or white blood cell count.

\section{Statistical analysis}

SPSS statistics software (version 23.0) was used for data statistics and mapping. Age was represented in Mean \pm SD (range) and gender in frequency and percentage. The quantized variables of blood parameters were expressed as mean \pm standard deviation. One way Analysis of variance (ANOVA) was applied to test the significance between the three groups. For between-group comparisons, Tukey HSD post hoc test was applied. A value of $<0.05$ was considered statistically significant in all statistical analyses.

\section{Results}

A total of 200 COVID-19 RT-PCR positive cases were included in the study. The mean age of the patients was $45.79 \pm 18.05$ ranging from 05 to 90 years. Among the cases, $73.50 \%$ were male and $26.50 \%$ were female. Based on the symptoms and as per the guideline of the Government of India Ministry of Health \& Family Welfare Directorate General of Health Services (EMR Division), cases were categorized as mild, moderate, and severely ill. Fifty cases each $(25.00 \%)$ were presented with mild and moderate symptoms and $50.00 \%$ cases were severely ill (Table 1). There was no significant difference on the baseline homogeneity comparison among the three groups.

The CBC and serum biochemistry parameters at the time of hospitalization were recorded for all the cases and are depicted in Table 2. Table 3 compares the blood count parameters profile in mild, moderate, and severely ill cases. The hemoglobin and platelet count did not differ significantly in cases with mild, moderate, and severely ill patients ( $\mathrm{p}=$ $0.069, \mathrm{p}=0.365$ ). However, the TLC was significantly different and higher in severely ill patients $(13,200 \pm 6,999.2)$ compared to the cases presented with mild and moderate symptoms $(12,100 \pm 6,488.41 \&$ $8,788.20 \pm 4,954.32, \mathrm{p}=0.001)$. The neutrophil ( $\mathrm{N} \%$ ) and Lymphocyte 
Table 1

Basic characteristics of the study subjects.

\begin{tabular}{ll}
\hline Characteristics & $\mathrm{N}=200(\%)$ \\
\hline Age (yrs) & $12(6.00)$ \\
Below 18 & $46(23.00)$ \\
$18-35$ & $60(30.00)$ \\
$36-50$ & $59(29.50)$ \\
$51-65$ & $23(11.50)$ \\
Above 65 & \\
Gender & $147(73.50)$ \\
Male: & $53(26.50)$ \\
Female: & $50(25.00)$ \\
Symptoms: & $50(25.00)$ \\
Mild symptoms Moderate symptoms & $100(50.00)$ \\
Severely ill & $140(70.00)$ \\
Fever & $05(2.5)$ \\
Nasal congestion & $110(55.00)$ \\
Cough & $40(20.00)$ \\
Fatigue & $25(12.5)$ \\
Poor appetite & $50(25.00)$ \\
Dyspnea & $05(2.5)$ \\
Diarrhea & \\
\hline
\end{tabular}

Data present as "frequency (\%).

( $\mathrm{L} \%$ ) count were also significantly different in groups $(\mathrm{p}=<0.001)$. The lymphocyte neutrophils ratio (L/N ratio) was higher in cases with moderate symptoms as compared to the mild and severely ill cases $(\mathrm{p}=$ 0.003).

Between groups comparisons of blood count parameters are depicted in Table 4. The mean difference of TLC, N\%, L\%, and M\% was significantly different between mild and moderate symptoms cases $(\mathrm{p}=0.030$, $\mathrm{p}=0.002, \mathrm{p}=0.004 \& \mathrm{p}=0.003)$. Between groups comparison of moderate vs. severely ill cases showed a significant difference in TLC (p $=0.000), \mathrm{N} \%(\mathrm{p}=0.000), \mathrm{L} \%(0.000)$, and $\mathrm{L} / \mathrm{N}$ ratio $(\mathrm{p}=0.002)$. Comparison of mild vs. severely ill cases did not show any significant difference (Table 3).

Serum biochemistry parameter values in different are depicted in Table 5. The serum urea level was significantly higher in severely ill cases $(65.52 \pm 41.04)$ compared with the mild $(47.16 \pm 23.77)$ and moderate symptom $(34.27 \pm 24.16)$ cases $(\mathrm{p}=<0.001)$. The serum ionic calcium (Ca), RBS, CRP, fibrinogen, prothrombin, INR, ferritin, andLDH level also differ significantly between mild, moderate, and severely ill cases $(\mathrm{p}=0.001, \mathrm{p}=<0.001, \mathrm{p}=0.002, \mathrm{p}=<00.1, \mathrm{p}=0006, \mathrm{p}=0.005$, $\mathrm{p}=<0.001$ and $\mathrm{p}=<0.001$ ) respectively.

Between group comparisons of the serum biochemistry parameters are depicted in Table 6. Between group comparison of mild vs. moderate symptoms cases showed significant difference in ionic Ca, RBS, CRP, fibrinogen, PT, INR, ferritin and LDH level ( $\mathrm{p}=0.025, \mathrm{p}=0.000, \mathrm{p}=$ $0.001,0.042, \mathrm{p}=0.013, \mathrm{p}=0.006, \mathrm{p}=0.000,0.033$ ) respectively. Comparison of the mild vs. severely ill cases showed significant difference in urea, fibrinogen and procalcitonin level $(p=0.005, p=0.000 \&$ $\mathrm{p}=0.048$ ) respectively. The comparison of moderate vs. severely ill cases showed significant difference in urea, ionic Ca, RBS, fibrinogen, PT, INR, ferritin and LDH level $(\mathrm{p}=0.000, \mathrm{p}=0.000, \mathrm{p}=0.000, \mathrm{p}=$ $0.000, \mathrm{p}=0.012, \mathrm{p}=0.021, \mathrm{p}=0.000 \&=0.000$ ) respectively.

\section{Discussion}

The present study included 200 patients who have gone to the admission to ICU, HDU and general ward with an almost 1:2 gender ratio. The most commonly observed symptoms were fever $(n=140)$, cough $(n=110)$, fatigue $(n=40)$, and dyspnea $(n=50)$. Very few patients presented with nasal congestion $(n=5)$, and diarrhea $(n=5)$. The findings of this study were consistent with the findings of previous study $(\mathrm{n}=41)$ which observed similar symptoms such as fever (70.00 vs. $98.00 \%$ ), cough (55.00 vs. $76.00 \%)$, and fatigue (20.00 vs. $44.00 \%)$ in more serious and fatal patients. ${ }^{8}$ The mild and common patients only presented with few common symptoms such as fever, cough, or fatigue;
Table 2

Blood count \& serum biochemistry parameters values cases at time of hospitalization $(\mathrm{N}=200)$.

\begin{tabular}{|c|c|c|c|c|}
\hline & $\begin{array}{l}\text { Mean } \pm \\
\text { SD }\end{array}$ & Median & Range & $\begin{array}{l}\text { Normal } \\
\text { Range }\end{array}$ \\
\hline $\begin{array}{l}\text { Hemoglobin } \mathrm{Hb}(\mathrm{g} / \\
\text { dl) }\end{array}$ & $\begin{array}{l}11.73 \pm \\
2.60\end{array}$ & 12.30 & $4.40-16.40$ & $13-17$ \\
\hline $\begin{array}{l}\text { Total Leucocyte } \\
\text { count (TLC) } \\
\text { (cells } / \mathrm{mm}^{3} \text { ) }\end{array}$ & $\begin{array}{l}11800 \pm \\
6629.15\end{array}$ & 10600 & $600.00-40300.00$ & $4000-11000$ \\
\hline Neutrophils (N) \% & $\begin{array}{l}75.54 \pm \\
11.40\end{array}$ & 78.00 & $26.00-90.00$ & $40-80$ \\
\hline Lymphocytes (L)\% & $\begin{array}{l}19.77 \pm \\
10.93\end{array}$ & 17.50 & $2.00-70.00$ & $20-40$ \\
\hline L/N Ratio & $\begin{array}{l}0.30 \pm \\
0.27\end{array}$ & 0.22 & $0.02-2.69$ & 2.69 \\
\hline M\% & $\begin{array}{l}1.98 \pm \\
0.65\end{array}$ & 2.00 & $1.00-6.00$ & $1.0-5.0$ \\
\hline $\begin{array}{l}\text { Platelet count } \\
\qquad\left(\mathrm{x} 10^{3} \text { cells } / \mathrm{mm}^{3}\right)\end{array}$ & $\begin{array}{l}169.18 \pm \\
88.09\end{array}$ & 149.00 & $10.00-411.00$ & $1.5-4.5$ \\
\hline SGOT (IU/L) & $\begin{array}{l}75.17 \pm \\
181.80\end{array}$ & 48.00 & $8.20-2536.10$ & $0-40$ \\
\hline SGPT (IU/L) & $\begin{array}{l}81.41 \pm \\
212.53\end{array}$ & 46.70 & $9.80-2960.20$ & $0-40$ \\
\hline ALP (IU/L) & $\begin{array}{l}284.81 \pm \\
203.98\end{array}$ & 232.05 & $26.90-1491.20$ & $50-270$ \\
\hline UREA (mg/dl) & $\begin{array}{l}53.12 \pm \\
36.01\end{array}$ & 41.00 & $14.50-212.50$ & $10-45$ \\
\hline $\begin{array}{l}\text { CREATNIN (mg/ } \\
\text { dl) }\end{array}$ & $\begin{array}{l}1.21 \pm \\
1.09\end{array}$ & 0.95 & $0.39-10.50$ & $0.6-1.5$ \\
\hline $\mathrm{Na}(\mathrm{mmol} / \mathrm{l})$ & $\begin{array}{l}135.70 \pm \\
5.36\end{array}$ & 135.80 & $120.40-169.50$ & $135-145$ \\
\hline $\mathrm{K}(\mathrm{mmol} / \mathrm{l})$ & $\begin{array}{l}4.24 \pm \\
0.92\end{array}$ & 4.05 & $2.28-9.16$ & $3.5-5.3$ \\
\hline $\mathrm{Ca}(\mathrm{mmol} / \mathrm{l})$ & $\begin{array}{l}4.11 \pm \\
0.61\end{array}$ & 4.20 & $1.08-6.24$ & $4.5-5.5$ \\
\hline RBS (mg/dl) & $\begin{array}{l}157.05 \pm \\
73.04\end{array}$ & 140.00 & $54.70-468.30$ & 79-149 \\
\hline CRP (mg/dl) & $\begin{array}{l}32.75 \pm \\
44.34\end{array}$ & 16.95 & $0.40-432.00$ & $0-6$ \\
\hline D dimer (ug/ml) & $\begin{array}{l}1.25 \pm \\
2.17\end{array}$ & 0.63 & 0.01-17.25 & $<0.5$ \\
\hline Fibrinogen (mg/dl) & $\begin{array}{l}426.12 \pm \\
106.05\end{array}$ & 416.00 & $152.00-650.00$ & $150-400$ \\
\hline INR & $\begin{array}{l}1.11 \pm \\
0.21\end{array}$ & 1.07 & $0.89-2.77$ & 2.77 \\
\hline Ferritin (ug/l) & $\begin{array}{l}327.60 \pm \\
190.69\end{array}$ & 282.40 & $6.20-816.30$ & $\begin{array}{l}\text { Male: } 30-220 \\
\text { Female: } 20- \\
110\end{array}$ \\
\hline LDH (IU/L) & $\begin{array}{l}820.59 \pm \\
406.95\end{array}$ & 724.35 & $84.70-2462.70$ & $240-480$ \\
\hline $\begin{array}{l}\text { Procalcitonin (ng/ } \\
\text { ml) }\end{array}$ & $\begin{array}{l}1.29 \pm \\
2.42\end{array}$ & 0.50 & $0.01-13.60$ & $0.02-0.3$ \\
\hline
\end{tabular}

as a result, the proportion of common symptoms in the present study was low. ${ }^{8}$

Current study uses basic hematology and serum biochemistry parameters in COVID-19 positive patients after admission to the hospital. The peak age of the symptoms was 36-65 years. There was no significant difference in the mean age and sex between mild, moderate, and severely ill patients. Our findings were consistent with previous studies ${ }^{8}$ In severely ill patients, lymphocytopenia was observed, lymphocyte count was lowered in severely ill patients compared to the mild and moderate symptoms patients and was significantly different between the three groups $(\mathrm{p}=<0.001)$. Thus showing the significant association with the disease severity. The findings of this study were consistent with other studies supporting lymphopenia as an effective predictor of severity in COVID-19. ${ }^{9}$ In this study group, TLC and neutrophil counts were higher in severely ill patients compared to the mild and moderate symptoms patients and were statistically significant $(\mathrm{p}=0.001$, $\mathrm{p}=<0.001)$. This finding was also supported by another similar study. ${ }^{10}$ Additionally, we have also found lowered $\mathrm{L} / \mathrm{N}$ ratio in severely ill patients compared to the mild and moderate symptoms ( $\mathrm{p}=0.003$ ). 
Table 3

Blood count parameters values in different categories of the cases $(\mathrm{N}=200)$.

\begin{tabular}{|c|c|c|c|c|}
\hline & \multicolumn{3}{|l|}{ Category } & \multirow[t]{3}{*}{ p-value } \\
\hline & mild symptoms & $\begin{array}{l}\text { moderate } \\
\text { symptoms }\end{array}$ & severely ill & \\
\hline & Mean \pm SD & Mean \pm SD & Mean \pm SD & \\
\hline $\mathrm{Hb}$ & $11.83 \pm 2.20$ & $11.00 \pm 3.17$ & $12.03 \pm 2.43$ & 0.069 \\
\hline TLC & $\begin{array}{l}1,2100 \pm \\
6,488.41\end{array}$ & $\begin{array}{l}8,788.20 \pm \\
4,954.32\end{array}$ & $\begin{array}{l}1,3200 \pm \\
6,992.07\end{array}$ & 0.001 \\
\hline $\mathrm{N} \%$ & $76.60 \pm 11.46$ & $69.12 \pm 11.25$ & $78.21 \pm 10.25$ & $<0.001$ \\
\hline $\mathrm{L} \%$ & $19.06 \pm 10.97$ & $25.76 \pm 10.60$ & $17.12 \pm 9.97$ & $<0.001$ \\
\hline L/N Ratio & $0.28 \pm 0.25$ & $0.41 \pm 0.24$ & $0.25 \pm .29$ & 0.003 \\
\hline M\% & $1.76 \pm 0.62$ & $2.18 \pm 0.56$ & $2.00 \pm 0.68$ & 0.005 \\
\hline $\begin{array}{r}\text { Platelet } \\
\text { count }\end{array}$ & $154.00 \pm 77.70$ & $176.46 \pm 90.05$ & $173.12 \pm 91.85$ & 0.365 \\
\hline
\end{tabular}

Abbreviation: Hemoglobin $\mathrm{Hb}(\mathrm{g} / \mathrm{dl})$, Total Leucocyte count (TLC) (cells/ mm3), Neutrophils (N) \%, Lymphocytes (L)\%, Lymphocyte/neutrophil L/N Ratio, Monocyte M\%, Platelet count (x10 $0^{3}$ cells $/ \mathrm{mm} 3$ ), (p value $<0.05$ was considered significant)(One way Analysis of variance (ANOVA) was applied to test the significance).

Table 4

Between group comparison of different blood count parameters $(\mathrm{N}=200)$.

\begin{tabular}{|c|c|c|c|c|c|c|}
\hline & \multicolumn{6}{|l|}{ Category } \\
\hline & \multicolumn{2}{|c|}{ Mild vs. moderate } & \multicolumn{2}{|c|}{ Mild vs. severely ill } & \multicolumn{2}{|c|}{$\begin{array}{l}\text { Moderate vs. severely } \\
\text { ill }\end{array}$} \\
\hline & $\begin{array}{l}\text { Mean } \\
\text { difference }\end{array}$ & $\begin{array}{l}\mathrm{p}- \\
\text { value }\end{array}$ & $\begin{array}{l}\text { Mean } \\
\text { difference }\end{array}$ & $\begin{array}{l}\mathrm{p}- \\
\text { value }\end{array}$ & $\begin{array}{l}\text { Mean } \\
\text { difference }\end{array}$ & $\begin{array}{l}\mathrm{p}- \\
\text { value }\end{array}$ \\
\hline $\mathrm{Hb}$ & 0.83200 & 0.243 & -0.199 & 0.897 & -1.031 & 0.057 \\
\hline TLC & $3,277.80$ & 0.030 & $-1,085.00$ & 0.593 & $-4,362.80$ & 0.000 \\
\hline N\% & 7.48 & 0.002 & -1.61 & 0.666 & -9.090 & 0.000 \\
\hline $\mathrm{L} \%$ & -6.70 & 0.004 & 1.94 & 0.528 & 8.640 & 0.000 \\
\hline $\begin{array}{l}\mathrm{L} / \mathrm{N} \\
\quad \text { Ratio }\end{array}$ & -0.1256 & 0.052 & 0.0319 & 0.771 & 0.1575 & 0.002 \\
\hline M\% & -0.420 & 0.003 & -0.24 & 0.079 & 0.180 & 0.237 \\
\hline $\begin{array}{r}\text { Platelet } \\
\text { count }\end{array}$ & -22.46 & 0.411 & -19.12 & 0.423 & 3.34 & 0.974 \\
\hline
\end{tabular}

Abbreviation: Hemoglobin $\mathrm{Hb}(\mathrm{g} / \mathrm{dl})$, Total Leucocyte count (TLC) (cells/ $\mathrm{mm} 3$ ), Neutrophils (N) \%, Lymphocytes (L)\%, Lymphocyte/neutrophil L/N Ratio, Monocyte M\%, Platelet count ( $\times 10^{3}$ cells $/ \mathrm{mm} 3$ ), ), (p value $<0.05$ was considered significant) Tukey HSD post hoc test was applied.

Lowered $\mathrm{L} / \mathrm{N}$ ratio may be indicative of the disease severity with the increased neutrophil count in response to infection resulting in the induction of lymphocyte apoptosis. ${ }^{11-15}$ In this study between-group analysis of hematological parameter values showed a significant difference in the TLC ( $\mathrm{p}=0.03), \mathrm{N} \%(\mathrm{p}=0.002), \mathrm{L} \%(\mathrm{p}=0.004)$, and $\mathrm{M} \%$ $(0.003)$ between the mild vs. moderate symptoms patients. In a comparison of moderate vs. severely ill patients, TLC $(\mathrm{p}=0.000), \mathrm{N} \%(\mathrm{p}=$ $0.000), L \%(p=0.000)$, and $\mathrm{L} / \mathrm{N}$ ratio $(0.002)$ showed the significant difference, highlighting the importance of these parameters values in the differentiation of severely ill patients from moderate at the time of admission. In an autopsy studies neutrophil infiltration in the pulmonary capillaries of the COVID-19 patients support the hypothesis that neutrophils, $\mathrm{L} / \mathrm{N}$ ratio may be associated with the mortality in the severely ill patients. These parameters confirm the dysregulated immune system in the identification of the patients who have lowered physiological stand-in to compete for the inflammatory affront. ${ }^{16,17}$

The inflammatory marker including creatinine, CRP, fibrinogen, prothrombin time, INR ferritin, and LDH also showed a statistical significance in between-group comparison. The mean level of fibrinogen, ferritin, LDH, and procalcitonin was higher in severely ill patients compared to the mild and moderate symptom patients. Other studies also support the hypothesis of this study. ${ }^{9,18}$ An elevated level of these inflammatory parameters may be looked for association with the disease intensification. Compared to the other similar study, this study did not
Table 5

Serum Biochemistry parameter values in different categories of the cases $(\mathrm{N}=$ 200).

\begin{tabular}{|c|c|c|c|c|}
\hline & \multicolumn{3}{|l|}{ Category } & \multirow[t]{3}{*}{ p-value } \\
\hline & \multirow{2}{*}{$\begin{array}{l}\text { mild } \\
\text { symptoms } \\
\text { Mean } \pm \text { SD }\end{array}$} & \multirow{2}{*}{$\begin{array}{l}\begin{array}{l}\text { moderate } \\
\text { symptoms }\end{array} \\
\text { Mean } \pm \mathrm{SD}\end{array}$} & \multirow{2}{*}{$\begin{array}{l}\text { severely ill } \\
\text { Mean } \pm \text { SD }\end{array}$} & \\
\hline & & & & \\
\hline SGOT & $\begin{array}{l}57.99 \pm \\
43.57\end{array}$ & $55.90 \pm 39.21$ & $\begin{array}{l}93.40 \pm \\
253.11\end{array}$ & 0.367 \\
\hline SGPT & $\begin{array}{l}56.95 \pm \\
37.21\end{array}$ & $59.36 \pm 55.91$ & $\begin{array}{l}104.67 \pm \\
295.75\end{array}$ & 0.303 \\
\hline ALP & $\begin{array}{l}315.46 \pm \\
214.07\end{array}$ & $\begin{array}{l}320.60 \pm \\
277.61\end{array}$ & $\begin{array}{l}251.59 \pm \\
143.43\end{array}$ & 0.069 \\
\hline UREA mg/dl & $\begin{array}{l}47.16 \pm \\
23.77\end{array}$ & $34.27 \pm 24.16$ & $\begin{array}{l}65.52 \pm \\
41.04\end{array}$ & $<0.001$ \\
\hline $\begin{array}{l}\text { CREATNIN mg/ } \\
\text { dl }\end{array}$ & $1.14 \pm 0.67$ & $0.98 \pm 0.78$ & $1.37 \pm 1.34$ & 0.088 \\
\hline $\mathrm{Na} \mathrm{mmol} / \mathrm{l}$ & $\begin{array}{l}135.88 \pm \\
3.95\end{array}$ & $134.77 \pm 3.17$ & $\begin{array}{l}136.08 \pm \\
6.67\end{array}$ & 0.357 \\
\hline $\mathrm{K} \mathrm{mmol} / \mathrm{l}$ & $4.14 \pm 0.74$ & $4.29 \pm 0.77$ & $4.27 \pm 1.07$ & 0.643 \\
\hline $\mathrm{Ca} \mathrm{mmol} / \mathrm{l}$ & $4.08 \pm 0.56$ & $4.39 \pm 0.41$ & $4.00 \pm 0.67$ & 0.001 \\
\hline RBS & $\begin{array}{l}169.52 \pm \\
67.77\end{array}$ & $105.94 \pm 29.23$ & $\begin{array}{l}176.38 \pm \\
79.06\end{array}$ & $<0.001$ \\
\hline CRP mg/dl & $\begin{array}{l}47.82 \pm \\
69.52\end{array}$ & $16.94 \pm 20.52$ & $\begin{array}{l}33.12 \pm \\
33.33\end{array}$ & 0.002 \\
\hline D dimer & $1.31 \pm 2.26$ & $0.85 \pm 1.36$ & $1.41 \pm 2.44$ & 0.321 \\
\hline Fibrinogen & $\begin{array}{l}403.28 \pm \\
69.71\end{array}$ & $\begin{array}{l}357.25 \pm \\
105.92\end{array}$ & $\begin{array}{l}471.99 \pm \\
99.33\end{array}$ & $<0.001$ \\
\hline PT & $15.47 \pm 3.36$ & $13.95 \pm 1.22$ & $15.28 \pm 2.81$ & 0.006 \\
\hline INR & $1.16 \pm 0.26$ & $1.03 \pm 0.09$ & $1.13 \pm 0.22$ & 0.005 \\
\hline Ferritin ug/l & $\begin{array}{l}349.13 \pm \\
178.99\end{array}$ & $\begin{array}{l}200.00 \pm \\
176.45\end{array}$ & $\begin{array}{l}380.63 \pm \\
174.73\end{array}$ & $<0.001$ \\
\hline IDH u/l & $\begin{array}{l}826.35 \pm \\
358.11\end{array}$ & $\begin{array}{l}628.93 \pm \\
303.21\end{array}$ & $\begin{array}{l}913.55 \pm \\
443.42\end{array}$ & $<0.001$ \\
\hline $\begin{array}{l}\text { Procalcitonin ng/ } \\
\quad \mathrm{ml}\end{array}$ & $0.64 \pm 0.41$ & $1.28 \pm 2.03$ & $1.63 \pm 3.05$ & 0.061 \\
\hline
\end{tabular}

Abbreviation: serum glutamic-oxaloacetic transaminase (SGOT) (IU/L), Serum glutamic pyruvic transaminase (SGPT) (IU/L), Alkaline phosphatase ALP (IU/L), UREA (mg/dl), CREATNIN (mg/dl), Serum sodium (Na) (mmol/l), Serum potassium (K) (mmol/l), Serum ionic calcium (Ca) (mmol/l), Random blood Sugar (RBS) (mg/dl), C- reactive protein (CRP) (mg/dl), D dimer (ug/ml), Fibrinogen (mg/dl), Prothrombin time (PT), International normalized ratio (INR), Ferritin (ug/l), Lactate dehydrogenase (LDH) (IU/L)), (p value $<0.05$ was considered significant) One way Analysis of variance (ANOVA) was applied to test the significance).

find any association of CRP in mild, moderate, and severely ill patients. ${ }^{19}$ In the present study group, the mean values of SGOT), SGPT, Serum $\mathrm{Na}$, ionic $\mathrm{Ca}$, and serum $\mathrm{K}^{+}$were not found to be statistically different between the mild, moderate and severely ill patients. In this study group, the D dimer level was higher in severely ill patients compared to the mild and moderate symptom patients. However other studies have found the statistically significant D dimer value in the ICU group compared to the HDU admitted patients ${ }^{10,20}$

However, in the present study between-group comparison CRP, fibrinogen, PT, INR, ferritin, and LDH showed a significant difference for discrimination of mild patients from moderate patients. In discrimination of mild vs. severely ill patients, fibrinogen and procalcitonin showed significant differences $(\mathrm{p}=0.000, \mathrm{p}=0.048)$. Findings in this study were supported by another similar study where mean procalcitonin level showed a higher level in ICU admitted patients; however, the difference was not significant. ${ }^{10}$ It will be of great importance to differentiate between the moderate and severely ill patients for this contagious disease. We have found urea level as showing a significant difference between the moderate vs. severely ill patients. Other parameters including Ca, fibrinogen, PT, INR, ferritin, and LDH showed a significant difference between these groups.

The study was limited that no healthy individuals and follow-up of hematological and serum biochemistry parameters were not included. Also underlying diseases of the patients were not recorded. We could not 
Table 6

Between group comparison of biochemical parameters values $(\mathrm{N}=200)$.

\begin{tabular}{|c|c|c|c|c|c|c|}
\hline & \multicolumn{6}{|l|}{ Category } \\
\hline & \multicolumn{2}{|l|}{ Mild vs. moderate } & \multicolumn{2}{|c|}{ Mild vs. severely ill } & \multicolumn{2}{|c|}{ Moderate vs. severely ill } \\
\hline & Mean difference & p-value & Mean difference & p-value & Mean difference & p-value \\
\hline SGOT & 2.088 & 0.998 & -35.41 & 0.500 & -37.498 & 0.460 \\
\hline SGPT & -2.406 & 0.998 & -47.7183 & 0.398 & -45.3123 & 0.436 \\
\hline ALP & -5.136 & 0.991 & 63.871 & 0.165 & 69.007 & 0.122 \\
\hline UREA mg/dl & 12.891 & 0.137 & -18.357 & 0.005 & -31.248 & 0.000 \\
\hline CREATNIN mg/dl & 0.160 & 0.738 & -.2388 & 0.410 & -0.3992 & 0.086 \\
\hline $\mathrm{Na} \mathrm{mmol} / \mathrm{l}$ & 1.116 & 0.552 & -.195 & 0.976 & -1.311 & 0.337 \\
\hline $\mathrm{K} \mathrm{mmol} / 1$ & -0.1538 & 0.683 & -.1342 & 0.679 & 0.0196 & 0.992 \\
\hline $\mathrm{Ca} \mathrm{mmol} / \mathrm{l}$ & -0.3074 & 0.025 & .0848 & 0.682 & 0.39220 & 0.000 \\
\hline RBS & 63.582 & 0.000 & -6.857 & 0.825 & -70.439 & 0.000 \\
\hline CRP mg/dl & 30.876 & 0.001 & 14.705 & 0.123 & -16.171 & 0.080 \\
\hline D dimer & 0.4616 & 0.539 & -.0995 & 0.962 & -0.5611 & 0.297 \\
\hline Fibrinogen & 46.026 & 0.042 & -68.711 & 0.000 & -114.737 & 0.000 \\
\hline PT & 1.522 & 0.013 & .189 & 0.912 & -1.333 & 0.012 \\
\hline INR & 0.129 & 0.006 & .0323 & 0.642 & -0.0967 & 0.021 \\
\hline Ferritin ug/l & 149.126 & 0.000 & -31.5056 & 0.557 & -180.63 & 0.000 \\
\hline $\mathrm{LDH} \mathrm{u/1}$ & 197.422 & 0.033 & -87.199 & 0.405 & -284.621 & 0.000 \\
\hline Procalcitonin ng/ml & -0.6412 & 0.375 & -.9875 & 0.048 & -0.34630 & 0.682 \\
\hline
\end{tabular}

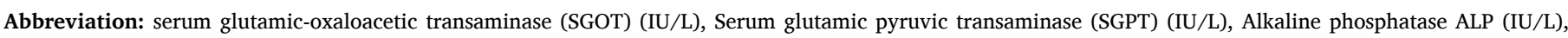

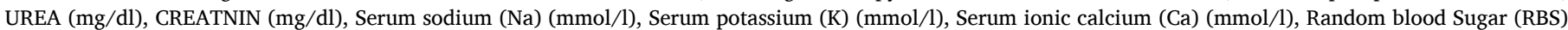

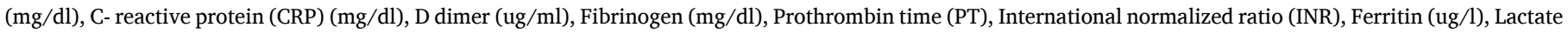
dehydrogenase (LDH) (IU/L).),(p value $<0.05$ was considered significant) Tukey HSD post hoc test was applied.

analyze and study, the prognosis of the included cases. Disease severity of patients was assumed based on admission to ICU, and not correlated clinically. This study suggests that hematological and serum biochemistry parameters can be used as a screening tool to identify patients requiring intensive care and thus allowing jeopardy stratification.

\section{Sources of support}

Nil.

\section{Declaration of competing interest}

The authors declare that they have no known competing financial interests or personal relationships that could have appeared to influence the work reported in this paper.

\section{References}

1 https://www.worldometers.info/coronavirus/country/india/.

2 http://www.chinacdc.cn/jkzt/crb/zl/szkb_11803/jszl_2275/202001/t20200121 211326.html.

3 Cascella M, Rajnik M, Cuomo A, Dulebohn SC, Di Napoli R. Features, Evaluation, and Treatment of Coronavirus (COVID-19). Statpearls [internet]; 2021 Jan 16.

4 Lu R, Yu X, Wang W, et al. Characterization of human coronavirus etiology in Chinese adults with acute upper respiratory tract infection by real-time RT-PCR assays. PloS One. 2012;7(6), e38638.

5 Huang C, Wang Y, Li X, et al. Clinical features of patients infected with 2019 novel coronavirus in Wuhan, China. Lancet. 2020;395(10223):497-506.

6 Bekdas M, Goksugur SB, Sarac EG, Erkocoglu M, Demircioglu F. Neutrophil/ lymphocyte and C-reactive protein/mean platelet volume ratios in differentiating between viral and bacterial pneumonias and diagnosing early complications in children. Saudi Med J. 2014;35(5):442-447.

7 Clinical Management Protocol: COVID-19, Government of India, Ministry of Health and Family welfare, Directorate General of Health Service (EMR Division), New Delhi, Version 3: 13 June 2020.

8 Yang X, Yu Y, Xu J, et al. Clinical course and outcomes of critically ill patients with SARS-CoV-2 pneumonia in Wuhan, China: a single-centered, retrospective, observational study. The Lancet Respir Med. 2020;8(5):475-481.

9 Tan L, Wang Q, Zhang D, et al. Lymphopenia predicts disease severity of COVID-19: a descriptive and predictive study. Signal Transduct targeted Ther. 2020;5(1):1-3.

10 Singh P, Kumar A, Singh S, et al. Utility of Routine Haematological Parameters and Infectious Biomarkers to Assess the Disease Severity in COVID-19 Positive Patients, Analysis and Early Trend from India. 2020.

11 Zahorec R. Ratio of neutrophil to lymphocyte counts-rapid and simple parameter of systemic inflammation and stress in critically ill. Bratisl Lek Listy. 2001;102(1):5-14.

12 O'Mahony JB, Palder SB, Wood JJ, et al. Depression of cellular immunity after multiple trauma in the absence of sepsis. J Trauma. 1984:24(10):869-875.

13 Dahn MS, Whitcomb MP, Lange MP, Jacobs LA. Altered T-lymphocyte subsets in severe sepsis. Am Surg. 1988;54(7):450-455.

14 Le Tulzo Y, Pangault C, Gacouin A, et al. Early circulating lymphocyte apoptosis in human septic shock is associated with poor outcome. Shock. 2002;18(6):487-494.

15 Barnes BJ, Adrover JM, Baxter-Stoltzfus A, et al. Targeting potential drivers of COVID-19: neutrophil extracellular traps. J Exp Med. 2020 1;(6):217.

16 Fox SE, Akmatbekov A, Harbert JL, Li G, Brown JQ, Vander Heide RS. Pulmonary and cardiac pathology in African American patients with COVID-19: an autopsy series from New Orleans. The Lancet Resp Med. 2020;8(7):681-686.

17 Yao XH, Li TY, He ZC, et al. A pathological report of three COVID-19 cases by minimally invasive autopsies. Zhonghua bing li xue za zhi Chin J Pathol. 2020;49: E009-9.

18 Wang L. C-reactive protein levels in the early stage of COVID-19. Med Maladies Infect. 2020;50(4):332-334.

19 Wang G, Wu C, Zhang Q, et al. C-reactive Protein Level May Predict the Risk of COVID19 Aggravation. InOpen Forum Infectious Diseases. US: Oxford University Press; 2020.

20 Chen N, Zhou M, Dong X, et al. Epidemiological and clinical characteristics of 99 cases of 2019 novel coronavirus pneumonia in Wuhan, China: a descriptive study. Lancet. 2020 15;395(10223):507-513. 